\title{
CONFERENCE REPORT: THE 19TH POLISH MALACOLOGICAL SEMINAR
}

\section{SEMINAR REPORT}

The 19th Polish Malacological Seminar was held in Stupsk (for those who do not know: a town temptingly close to the seaside, about 30 minutes by bus), on September 22nd-24th which is an unusual time, since we usually have our seminars in spring. This year the Seminar was a bit of a "last-minute offer": the person(s) who should have organised it, failed to do so, and we only realised in May that it was ALMOST too late to organise anything. But fear not, no true malacologist would miss a chance of having a good time, and we organised everything rather rapidly. The main organiser was The President of The Association of Polish Malacologists, ADAM WOJCIECHOWSKI (previously based in Poznań, now in Słupsk, hence the location), aided loyally by the very same people who begged him to take the responsibility and finally bribed him with an offer to co-organise the meeting (TOMASZ K. MALTZ \& BEATA M. POKRYSZKO). In spite of the rather short notice, the attendance was no poorer than during the last few meetings: there were about 60 people, most of them with lectures, posters, short communications etc., and most either arriving after the Seminar began or departing before it ended. Some of the people who

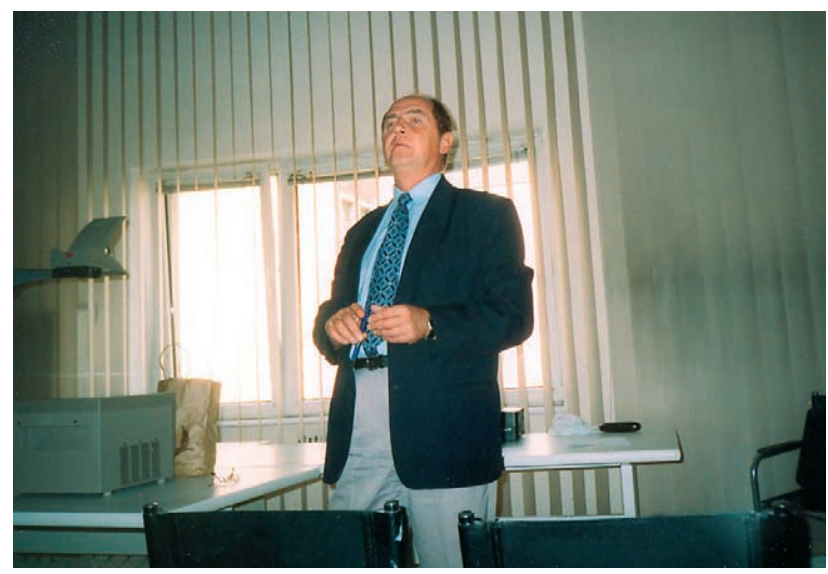

The Main Organiser during the General Assembly reacted quite enthusiastically to our first circular (including many of our Ukrainian neighbours), finally did not appear but at least sent their summaries.

The range of problems discussed was as wide as during the last few Seminars: terrestrial and aquatic ecology and faunistics, snail and bivalve physiology, taxonomy and variation, life cycles, bionomics and population biology of gastropods and bivalves, growth patterns and variation, trematode effect on various aspects of snail physiology and behaviour, karyology, introduced species and species protection. Contributions dealing with mollusc reaction to human impact (radionuclides, heavy metals, biomonitoring) and with applied aspects of malacology: snails that we consume and slugs that consume cultivated plants (see also abstracts below) were many. The nomenclature adopted by the CLECOM was discussed in a rather tempestuous manner (one of those situations when everybody agrees, but they are too emotional about it to agree quietly), and duly criticised. The posters (about twenty) were all very beautiful, and the best-poster contest was won by AGNIESZKA MiCHALIK-KUCHARZ from the Silesian University (congratu-

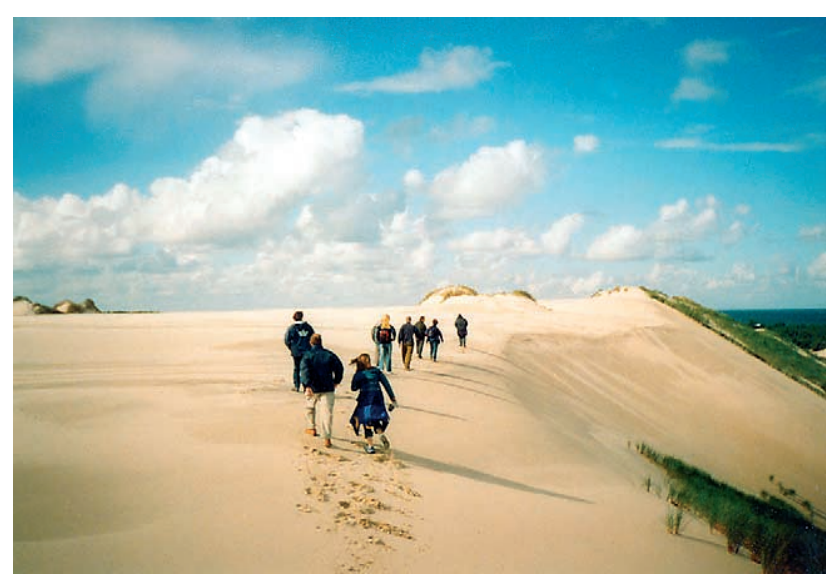

Malacologists at large 
lations, Agnieszka!). As usual there were many young malacologists, doctoral students mostly, some with very good posters/papers. Will they ever find jobs? Will their jobs be malacological?

During the General Assembly of The Association of Polish Malacologists it was decided that for the next - 20th!!! - Seminar we would go to Krościenko in the Pieniny Mts, where we had the 1st Malacological Seminar very long ago.

Most of us stayed in one hotel, only very few people were stationed in another. Those who stayed in our hotel had a lot of opportunities for unofficial discussion and small, unoffical banquets (though we had a very good, big, official banquet as well). One evening ANDRZEJ WIKTOR showed us magnificent slides from his malacological trip to China - not only snails but lots of beautiful nature and architecture.

There was an excursion to the Słowiński National Park. Thanks to the permission from the Park's Direc- tor we could go to places normally inaccessible to tourists. The weather was fine, though windy, and we saw the famous and very spectacular wandering dunes (though we would have had to stay much longer to actually SEE them wander).

The Book of Abstracts, hastily produced two days before the Seminar started, with a Eucobresia on the cover, includes abstracts ranging from a few lines to over two pages, most of them in Polish and some few in English. In accordance with my firm belief that other malacologists should know what we do, the abstracts have been translated and in many cases edited and/or abbreviated behind the authors' back. The institution names are given in Polish, like in the Abstract Book.

\section{BEATA M. POKRYSZKO}

Museum of Natural History, Wrocław University, Sienkiewicza 21, 50-335 Wrocław, Poland (e-mail: bepok@biol.uni.wroc.pl)

\section{ABSTRACTS FROM THE 19TH MALACOLOGICAL SEMINAR}

POPULATION STRUCTURE AND GROWTH RATE IN ANODONTA CYGNEA (L.) FROM THE BACKWATER ZONE OF THE SULEJOWSKI RESERVOIR

\section{A. ABRASZEWSKA-KOWALCZYK}

Katedra Zoologii Bezkręgowców i Hydrobiologii, Uniwersytet Łódzki

Results of the 1998 and 2003 studies on A. cygnea in a flow canal of the backwater zone of the Sulejowski reservoir were compared. The number of individuals was found to have dropped (from 10 to 5 per $\mathrm{m}^{2}$ ), while the dominant age class shifted from individuals aged $3-4$ to 5-7 years. Compared to the earlier study, larger colonies of A. cygnea were found in the reservoir below the canal, and on the other side of the island separating the canal from the river bed. The density there reached 30 indiv. $/ \mathrm{m}^{2}$, and the low mean age (2-5 years) indicates a recent origin of these colonies.

\section{THE EFFECT OF HABITAT ALKALISATION IN THE ŚWIETOKRZYSKI REGION ON THE SNAILS OF BIAŁE ZAGŁËBIE}

\section{J. BARGA-WIECGAWSKA}

Instytut Biologii,

Świętokrzyska Akademia Pedagogiczna, Kielce

Białe Zagłębie is an area of intense rock exploitation and cement industry. Since the beginning of the sixties the alkaline dust from cement plants has been causing soil alkalisation. The snail fauna was surveyed within a more extensive monitoring programme, in 1993-1994 and 2000-2001, using Oekland method, in an oak-hornbeam forest, a pine forest and on a humid meadow. The numbers of snail species found in 1993/94 and 2000/01 were 45 of 15 families (41 terrestrial, 4 aquatic) and 48 of 16 families ( 44 terrestrial and 4 aquatic). The species numbers and densities in the studied habitats were: oak-hornbeam 29 species and 702 indiv. $/ \mathrm{m}^{2}$ in 2000/01, 27 species and 690 indiv. $/ \mathrm{m}^{2}$ in $1993 / 94$; pine 23 species and 775 indiv. $/ \mathrm{m}^{2}$ in 2000/01, 27 species and 750 indiv. $/ \mathrm{m}^{2}$ in 1993/94; meadow 38 species and 946 indiv. $/ \mathrm{m}^{2}$ in 2000/01, 30 species and 920 indiv./ $\mathrm{m}^{2}$ in 1993/94. The number of species and the density were similar between the study periods. The unusually high number of species and individuals in the pine forest may suggest its disturbed character.

\section{ENZYMATIC ACTIVITY IN ZEBRA MUSSEL SPERMATOZOA}

\author{
J. BIAŁKOWSKA ${ }^{1} \&$ J. GŁOGOWSKI ${ }^{1,2}$ \\ ${ }^{1}$ Katedra Ekologii Ewolucyjnej, \\ Uniwersytet Warmińsko-Mazurski, Olsztyn \\ ${ }^{2}$ Zakład Andrologii Molekularnej PAN, Olsztyn
}

The activity of acrosin, acid and alkaline phosphatase, arylosulphatase and $\mathrm{B}-\mathrm{N}$-acetylglucosaminidase in zebra mussel spermatozoa was determined spectrophotometrically. The activity of acid phosphatase and B-N-acetylglucosaminidase was $0.56 \pm 0.31$ and $0.7 \pm 0.32 \mathrm{U} / 10^{6}$ spermatozoa; the activity of the remaining enzymes was below the sensitivity of the method used. Cytochemical staining with the Gomori 
method in order to locate acid phosphatase resulted in an intense dark brown staining of the whole spermatozoon, indicating the presence of the enzyme in the acrosomal region, nuclear envelope and/or plasmalemma.

\section{DISTURBANCE OF CILIARY ACTIVITY IN UNIONIDAE FROM RADIONUCLIDE- -CONTAMINATED TERRITORIES}

\section{T. V. CHERNOMAZ}

Uniwersytet Pedagogiczny w Żytomierzu, Ukraina

Unionid bivalves in radionuclide-contaminated areas of Ukraine (zones II: $15-39.9 \mathrm{Ku} / \mathrm{km}^{2}$, and III: $5-14.9 \mathrm{Ku} / \mathrm{km}^{2}$ ), are subject to chronic internal and external irradiation. Accumulation coefficients of ${ }^{90} \mathrm{Sr}$, determined for Batavusiana musiva, Unio conus, $U$. rostratus gentilis, Anodonta cygnea, Colletopterum piscinale, Pseudanodonta complanata, ranged from 12.7 to 137.5 , and coefficients of bottom biological accumulation - from 1.5 to $42.3 .{ }^{137} \mathrm{Cs}$ was found in bodies of molluscs in lower quantities compared to ${ }^{90} \mathrm{Sr}$. In the unionids from the radionuclide-contaminated territories the beating frequency of ciliated epithelium was found to increase by $2.1-6.6 \%$ (increased metabolic rate), while the duration of ciliary motion decreased by 15.4-48.7\%, compared to molluscs from unpolluted zones. The increase in beating frequency of the epithelium was correlated with the decreased duration of the periods of ciliary motion. There was a positive correlation between the ciliary beating frequency and the radionuclide content in the body, and a negative correlation between the duration of ciliary activity and the radionuclide content.

\section{CIRCADIAN ACTIVITY OF HELICOPSIS STRIATA}

\section{S. CHOLEWA}

Zakład Zoologii Ogólnej, Uniwersytet Adama Mickiewicza, Poznań

The activity of Helicopsis striata was studied in July and August 2003 in the steppe nature reserve Pamięcin. The study included four 24-hour observation sessions (2/3 July, 16/17 July, 1/2 August, 17/18 August), on a plot of $5 \times 5 \mathrm{~m}$. The temperature and relative humidity were measured $15 \mathrm{~cm}$ above the ground. Active individuals were observed at a humidity exceeding $81 \%$ and temperature of $8-21^{\circ} \mathrm{C}$. The activity reached its peak (over $80 \%$ observed specimens) in the night and early morning hours (2.00-7.00) when there was dew. During long rainless periods a large proportion of individuals ( $72 \%$ adult, 37\% young) showed no activity (aestivation). No individuals were active during daytime, even after intense rains.

\section{PRELIMINARY OBSERVATIONS ON THE BIOLOGY OF AND DAMAGE CAUSED BY OXYCHILUS CELLARIUS (O. F. MÜLL.)}

\section{E. DANKOWSKA}

Katedra Metod Ochrony Roślin, Akademia Rolnicza, Poznań

In western Poland, Oxychilus cellarius lives in natural habitats as well as in gardens, greenhouses and cellars; when numerous it can seriously damage greenhouse plants. It lays batches of 4-12 eggs (mean 7.2). The eggs are smooth, white, $1.2 \times 1.3 \mathrm{~mm}$. At $18^{\circ} \mathrm{C}$ the incubation takes $28-32$ days, at $5^{\circ} \mathrm{C}-93-94$ days. The snails reach maturity at the age of 6-7 months. In the laboratory $O$. cellarius preferred animal food, in the greenhouse where it appeared in masses, it caused much damage to ornamental plants.

\section{MOLLUSCS OF SMALL MIDFIELD WATER BODIES OF THE REGION OF TARNOWO PODGÓRNE (W POLAND)}

\section{B. GOŁDYN, E. KORALEWSKA-BATURA}

Zakład Zoologii Ogólnej, Uniwersytet Adama Mickiewicza, Poznań

Thirty small ponds located in the upper section of the Sama River valley were studied with respect to their malacofauna. The ponds differed in characters that might affect their mollusc fauna: permanent/temporary character, degree of isolation, bottom sediments, vegetation etc. Benthological samples were taken in the summer 2002 , with a $20 \times 30 \mathrm{~cm}$ net of $1 \times 1 \mathrm{~mm}$ mesh, towed along the bottom for $0.5 \mathrm{~m}$. Thirty samples, adding up to $3 \mathrm{~m}^{2}$ bottom, were taken from each pond. The samples were hand-sorted, and physico-chemical parameters of water were analysed. A total of 13 snail and 3 bivalve species were found (60,000 specimens). The mollusc communities varied from malacocenoses consisting of one or two planorbid species (Anisus leucostomus Mill., Segmentina nitida O. F. Müll.) to ones comprising up to 14 species. The mollusc density ranged from a few dozen to several thousand indiv. $/ \mathrm{m}^{2}$. The species richness and abundance seemed to be affected mainly by the permanent/temporary character of the ponds and the number of available microhabitats. 


\section{TERRESTRIAL SNAILS OF SELECTED HABITATS IN TOWNS OF MIDDLE POMERANIA}

\section{E. GÓRSKA, B. PAKUŁA}

Zakład Zoologii i Fizjologii Zwierząt, Pomorska Akademia Pedagogiczna, Słupsk

The snail fauna of Kołobrzeg, Ustka, Słupsk, Lębork, Kościerzyna and Barwice was surveyed in 1993-2003. The material was collected in parks, allotment gardens, cemeteries, forests and meadows within town boundaries (total: 74 sites), as well as in cellars, rubbish dumps and hedges. A total of 49 species were found, representing 17 families; the highest numbers of species were found in Lębork (38) and Ustka (36); only 23 species were present in each of the remaining towns. Ten species were common to all the towns (Succinea putris, Cochlicopa lubrica, Vallonia pulchella, Oxychilus draparnaudi, Limax maximus, Bradybaena fruticum, Trichia hispida, Cepaea hortensis, C. nemoralis, Helix pomatia) while six species were found in one town each (Succinea elegans, Limax cinereoniger, Clausilia bidentata, C. dubia, Laciniaria plicata, Euomphalia strigella). The most common species were Cepaea nemoralis (65 sites), Trichia hispida (54 sites) and C. hortensis (39 sites).

\section{DIGENETIC TREMATODE INFECTION IN LYMNAEA STAGNALIS (L.) FROM SELECTED WATER BODIES}

\section{B. GRYGON-FrANCKIEWICZ, E. ŻBIKOWSKA}

Zakład Zoologii Bezkręgowców, Instytut Biologii Ogólnej i Molekularnej, Uniwersytet Mikołaja Kopernika, Toruń

The water bodies studied in 1998-2002 in the region of Toruń, Konin and in the Iławsko-Ostródzkie Lakeland differed in their abiotic and biotic conditions. A total of 1,546 L. stagnalis from 15 lakes and 5 ponds were examined. The extensity of infection was the highest $(65-90 \%$, mean $77 \%$ ) in snails from small, shallow ponds while in lakes it ranged from $4 \%$ to $49 \%$ (mean 28\%). The reasons for the high extensity of infection in ponds were the high population density and easy access to ultimate hosts: water birds and frogs. Less abundant snail populations in the lakes made the transmission of parasites more difficult; besides, other snail species - though infection-resistant - could limit the density of infected Lymnaea. In much polluted waters the extensity of infection was higher compared to snail populations from waters of high quality.

\section{SELECTED ASPECTS OF LIFE HISTORY OF VIVIPARUS VIVIPARUS L.}

\section{B. JAKUBIK}

Katedra Ekologii i Ochrony Środowiska, Akademia Podlaska, Siedlce

The following life cycle parameters of Viviparus viviparus were determined based on an over 10-year study: life span and its correlation with adult size, growth rate in mature and immature snails, duration of reproductive period, copulation mode, number of embryos per female and per lifetime, their development rate and ways of their protection, energy expenditure on further growth versus reproduction, mortality. In a population of $V$. viviparus from a dam reservoir, at a high mortality, the snails matured at a smaller size and started reproducing earlier, compared to the snails from the adjacent section of the river.

\section{EFFECT OF LIGHT ON BEHAVIOUR OF DREISSENA POLYMORPHA}

\section{J. KOBAK}

Zakład Zoologii Bezkręgowców, Instytut Biologii Ogólnej i Molekularnej, Uniwersytet Mikołaja Kopernika, Toruń

The effect of light intensity and wave length on the behaviour of zebra mussel was studied in a dark room, on Petri dishes with half of their lids covered with black paper. The bivalves (10 per dish) were placed on the border between the light and dark zones, and illuminated with a dark room lamp (bulb 40W, $0.5 \mathrm{~m}$ above the dish) with an appropriate filter. The position of bivalves was checked after $24 \mathrm{hrs}$. In experiment 1 - white light of intensity 0 (control), $0.6,1.2$, 6,16 and $1151 \times-$ the bivalves reacted at a light intensity of $1.2 \mathrm{l} \times$ or higher. Blue (300-500 nm, maximum $400 \mathrm{~nm})$, green $(450-650 \mathrm{~nm}$, maximum $530 \mathrm{~nm})$, red (>650 nm, maximum $700 \mathrm{~nm}$ ) and white light (16 lx) were used in experiment 2. All the colours evoked a distinct reaction. The intensity of locomotion in various light conditions was estimated based on the length of traces left on the sandy substratum. At a uniform light $(161 \times)$ or in total darkness the bivalves covered an average distance of $221 \mathrm{~mm}$ in $24 \mathrm{hrs}$. When they could choose between the light and dark halves of the dish, their mobility was twice smaller (109 $\mathrm{m})$ and almost completely limited to the dark zone. 


\section{SETTLING AND DISTRIBUTION OF DREISSENA POLYMORPHA ON SUBSTRATA OF VARIOUS SHAPE AND ORIENTATION}

\section{J. KOBAK}

Zakład Zoologii Bezkręgowców, Instytut Biologii Ogólnej i Molekularnej, Uniwersytet Mikołaja Kopernika, Toruń

Settling and distribution of the zebra mussel were studied in the dam reservoir of the power plant Włocławek, on substrata exposed at ca. $5 \mathrm{~m}$ depth, from July till October of 2000-2002. In experiment 1 the bivalves settled on glass substrata of convex, concave or flat surface; all the substrata were used indiscriminately in places sheltered from water current. When the current was strong (up to $1200 \mathrm{~m}^{3} / \mathrm{sec}$ ) the density of bivalves on concave substrata was significantly higher. Experiment 2 was aimed at determining the effect of the position of the substratum (plastic plates). There were no significant differences in the density of bivalves between vertical and horizontal plates, with their surface or edge exposed to the current. The bivalves were more numerous on the side sheltered from the current and on the upper surface of horizontal plates. The distribution was clustered (Lloyd index $>1$ ); the bivalves preferred the vicinity of plate edges (all edges of horizontal and upper edges of vertical plates). The most probable reason for such a distribution was movement of settled individuals which then stopped having arrived at the edge. The bivalve density on substrata of different outline (round and square) and size (100 and $\left.56.25 \mathrm{~cm}^{2}\right)$ was similar.

\section{LITHOGLYPHUS NATICOIDES (C. PFEIFFER, 1828)} IN LAKE MIKOŁAJSKIE

\section{A. KOŁODZIEJCZYK}

Zakład Hydrobiologii, Instytut Zoologii, Uniwersytet Warszawski

Lithoglyphus naticoides, originally a Pontic species, has spread considerably to the north and west since the thirties of the 19th c. In Lake Mikołajskie it was first found in 1997, in one site, depth 2.5 and $5.5 \mathrm{~m}$, and was present there during the next four years. In July 2003, when samples of fauna were taken in 11 sites, from depths of 0.5 or 1.0 to the maximum depth of occurrence of submerged plants, it was found in four sites adjoining one another and located at the western shore, in its mid part. Live specimens were found at $1.0-3.5 \mathrm{~m}$, shells down to $5.5 \mathrm{~m}$. Such an insular occurrence provides no clue to the way of expansion of the species into the lake.

\section{SENSITIVITY OF VARIETIES OF RAPE TO SLUG DAMAGE}

\section{J. KOZŁOWSKI, T. KA€USKI}

\author{
Instytut Ochrony Roślin, Poznań
}

The rape Brassica napus L. var. oleifera is often damaged by slugs; its commonly cultivated new varieties of a low content of erucic acid and glucosinolanes may be more palatable to slugs and thus more sensitive to damage. The most common pest in rape plantations is Deroceras reticulatum, accompanied by other species of the same genus, and by members of the genus Arion. The aim of the study was to determine the sensitivity of young plants of various varieties of rape to damage by $D$. reticulatum and Arion lusitanicus. The conditions of the experiment were: day temperature $19^{\circ} \mathrm{C}$, night temperature $16^{\circ} \mathrm{C}, \mathrm{RH} 95 \%$, day length $15 \mathrm{hrs}$. Seedlings of 16 varieties of rape were sown in plastic containers. For each slug species 30 young plants (2-3 leaves) of each variety were tested, in 6 trials of 5 plants each. Damage to the tissue was estimated daily based on a 4-degree scale. The results were subject to variance analysis and Fisher test, $\alpha=$ 0.05 . The differences in the slug preferences to various varieties became significant on the 13th day. Depending on the variety, $D$. reticulatum damaged 33-63\%, and A. lusitanicus 35-45\% plant mass. D. reticulatum caused the strongest damage to var. Bermuda, and the smallest to var. Marita; in the case of $A$. lusitanicus var. Lirajet was the strongest damaged, and varieties Bristol, Rasmum and Kana the least damaged. Both species considerably damaged var. Baldur.

\section{BOTTOM MACROFAUNA OF SINK-HOLE PONDS WITH SPECIAL REFERENCE TO GASTROPODA}

\section{A. KRÓlCZYK}

Zakład Hydrobiologii, Katedra Ekologii, Wydział Biologii i Ochrony Środowiska, Uniwersytet Śląski, Katowice

Five sink-hole ponds in the eastern part of the Upper Silesian Industrial region were studied from may 2001 till April 2002. Quantitative samples were taken in shallow littoral, with Ekman grab of working area $225 \mathrm{~cm}^{2}$. Qualitative samples were taken with bottom scraper. High concentration of chlorides, sulphates, phosphates and high electrolytic conductivity make such reservoirs a specific habitat for aquatic fauna. Twelve snail species were found, dominants (D $>20 \%$ ) being Gyraulus crista and Segmentina nitida. Menetus dilatatus, previosuly known only from the Konin lakes, was found in one reservoir. Six to ten species were found in each site. The presence of some common species was found to depend on the quality of bottom sediments: Radix peregra on muddy sediments with 
carbonaceous shales, G. albus on sandy-muddy bottom with thick layer of plant debris, and G. crista with muddy-detritus bottom with carbonaceous shales.

\section{TENDENCIES OF CHANGES IN THE UNIONID FAUNA IN LAKE MIKOŁAJSKIE WITHIN 30 YEARS}

\section{K. LEWANDOWSKI}

Katedra Ekologii i Ochrony Środowiska, Akademia Podlaska, Siedlce

The 2002 study in Lake Mikołajskie was an exact repetition of the 1972 and 1987 studies. Samples were always taken in the same 10 sites, at the same depth and with the same methods. Two unionid species were found in 2002: Unio tumidus and $U$. pictorum. The number of species was smaller than on the previous occasions: in 1987 three species were noted (the above two plus Anodonta anatina), and in 1972 five (the three already mentioned, plus A. cygnea and $A$. complanata). A. complanata was sporadic in $1972(0.2 \%$ all unionids), but $A$. cygnea was more numerous than $U$. pictorum. The absence of A. anatina in 2002 is surprising - 30 years earlier it was a dominant species (70\% all unionids), though in 1987 it was twice less abundant than $U$. tumidus. The depth range of occurrence of unionids has decreased from $0.5-5.5 \mathrm{~m}$ in 1972 to $0.5 \mathrm{~m}$ in 2002; the number of sites has dropped from ten in 1972 to four in 2002, and the age of the oldest individuals has decreased from 9-10 years in 1972 to 6 years in 2002 .

\section{DYNAMICS OF MOLLUSC COMMUNITIES UNDER HUMAN IMPACT - SINK-HOLE PONDS IN CZUŁÓW NEAR KATOWICE}

\section{LEWIN}

Zakład Hydrobiologii, Katedra Ekologii, Wydział Biologii i Ochrony Środowiska, Uniwersytet Śląski, Katowice

The 1993-2002 survey included 7 sink-hole ponds resulting from coal bed exploitation by the Murcki mine in Czułów. Physico-chemical properties of water were determined, macrophytes were identified and malacocenoses analysed. Twenty one mollusc species were found. In 1997 there was a mass expansion of Potamopyrgus antipodarum (Gray); since 2000 Ferrissia wautieri (Mirolli) has established a permanent population; in 2001-2002 protected bivalve species appeared: Musculium lacustre (O. F. Müll.) and Pisidium casertanum (Poli). Physella acuta (Drap.) and Hippeutis complanatus (L.), rare in the Silesian Upland, and Stagnicola palustris (O. F. Müll), atypical for such reservoirs, were found in the sink-hole ponds. Gyraulus albus (O. F. Müll.) was associated with fine-grained bottom sediments, Bithynia tentaculata (L.) avoided macerated macrophyte tissues. There was no significant correlation between the density of molluscs and the physico-chemical properties of water. Changes under human impact observed in 1993-2002 involved qualitative and quantitative composition of malacocenoses and appearance of the introduced $P$. antipodarum.

\section{BIVALVES - COLONISERS IN THE LOWER DANUBE}

\section{A. V. LIASHENKO ${ }^{1}$, O. O. SiniCyNA ${ }^{2}$, E. V. VOLOSHKEVICH ${ }^{2}$ \\ ${ }^{1}$ Instytut Hydrobiologii NAN Ukrainy ${ }^{2}$ Dunajski Rezerwat Biosfery NAN Ukrainy}

Two new bivalve species appeared in the Danube and adjacent bays in Ukraine: Sinanodonta woodiana Lea and Corbicula fluminea (O. F. Müll.). S. woodiana was first found in 1999 in the Sasyk canal of the Danube delta, in 2001 single individuals were noted in Anankinom oxbows, and small colonies appeared in Kuril shallows ( 3 indiv. $/ \mathrm{m}^{2}$ ). The maximum length of the bivalves was $19 \mathrm{~cm}$. In 2002 bivalve colonies of a biomass exceeding $500-800 \mathrm{~g} / \mathrm{m}^{2}$ were found in the whole delta. The first two specimens of C. fluminea in the Danube delta were found in 2000, their shell lenght being 0.8 and $1.9 \mathrm{~cm}$. Single individuals were also noted in the lower branch of Limbowsko and Starostambulsko. In 2001 the species was present in virtually all zones of the delta. It preferred open or poorly vegetated shallows of sandy, sandy-muddy and muddy bottom; the depth range observed was $0.2-11$ $\mathrm{m}$. Most specimens were 9-13 mm long, the mean density in 2002 was $20-25$ indiv. $/ \mathrm{m}^{2}$.

\section{INTENSIFICATION OF ROMAN SNAIL (HELIX POMATIA) REPRODUCTION IN FARM CONDITIONS IN 2003}

\section{LIGASZEWSKI, A. ŁYSAK, Z. MACH-PALUSZKIEWICZ}

Instytut Zootechniki w Balicach k. Krakowa, Balice

The studies were conducted in a greenhouse of $24.5 \mathrm{~m}^{2}$, and involved snails at least 3 years old $(3+)$ in 2002, and snails aged $2+$ to $3+$ in 2003 . The total number of snails was 1,550 , mean body mass $19.80 \mathrm{~g}$, mean shell diameter $32.91 \mathrm{~mm}$. In 2003, till July 16th, out of 1,066 snails which laid eggs, $18.34 \%$ laid eggs for the second time, and $1.52 \%$ for the third time in the season. Most productivity indices were significantly higher in the first batch compared to the second. During 48 days, 54.5 batches were laid with a total of 1,210 eggs per $1 \mathrm{~m}^{2}$ greenhouse. The number of batches and eggs produced daily from the beginning of the season till July 16th was positively correlated with time, while the mean batch mass, number of eggs per batch and mean egg mass were negatively correlated with the time fac- 
tor. Using younger snails, aged 2+-3+, for reproduction seems to yield good results in farm conditions.

\section{THE EFFECT OF INVASION OF LARVAE}

OF FASCIOLA HEPATICA ON THE ACTIVITY

OF GLUCOSE-6-PHOSPHATASE IN THE

ALBUMEN GLAND OF LYMNAEA TRUNCATULA

\section{A. ŁAPETA}

Instytut Biologii i Ochrony Środowiska, Pomorska Akademia Pedagogiczna, Słupsk

The snails came from a laboratory culture, and were infected with invasive forms of $F$. hepatica also obtained in the laboratory. G-6-P was detected with ultracytochemical methods. In the initial period after infection (20th day) the G-6-P activity was higher than in control snails, while at the end of larval parasitic phase (60th day) the activity was weaker. The increase in the activity of the enzyme was probably caused by the toxic and energy-exhausting effect of developing larvae, while the decrease in its activity could result from exhaustion of reserves of the host's nutritive substances.

\section{LIFE CYCLE AND POPULATION DYNAMICS OF HELICODONTA OBVOLUTA (O. F. MÜLL.) (GASTROPODA: PULMONATA: HELICIDAE)}

\section{T. K. MALTZ}

Muzeum Przyrodnicze, Uniwersytet Wrocławski

Courtship behaviour of $H$. obvoluta includes meeting, recognition, courtship dance, copulation, rest and parting. Sperm transfer is reciprocal, no spermatophores were found. Copulation takes place in a horizontal position, late in the evening or in the night. Eggs are laid in spring and autumn, under bark or in rotting wood. The eggs are white, calcified, oval $(2.10-2.85 \times 2.00-2.60 \mathrm{~mm}), 9-27$ per batch. Incubation takes 14-31 days, hatching is asynchronous, lasting 1-4 days. No egg cannibalism was observed. The mean time from hatching to maturity is 379 days, the growth being quicker in the initial phase and just before lip formation. In the reproductive system the gonad is the first to develop; the development of male and female copulatory organs is synchronous. In the initial stage of gonad development (3-4 whorls) mitotically dividing cells prevail, and the first oocytes and spermatocytes appear. At 5-whorl stage the number of cells in meiotic prophase increases, the first growing oocytes appear, while there are no spermatids and spermatozoa. All the cells characteristic of a mature gonad are present in lip-building snails. The gonad of mature snails contains oocytes and spermatozoa throughout the year, but the number and size of oocytes change seasonally, with large vitellogenic oocytes present from April till the beginning of July and from the end of August till October. Growing oocytes are visible in August and December. Newly-hatched snails appear from April till the beginning of July and from the end of August till the beginning of October. The spring generation may complete their growth or winter over as 4-5-whorl snails, the autumn generation always winter over as juveniles. The life cycle is a three-year cycle, with not more than six batches produced per lifetime. The activity is the highest in the spring and autumn, the winter torpor lasting from the end of October till the beginning of April.

\section{GAMETE PRODUCTION DYNAMICS IN VERTIGO PUSILLA O. F. MÜLL. (GASTROPODA: PULMONATA: VERTIGINIDAE)}

\section{MAZurkiewicz ${ }^{1}$, B. M. PokryszKO ${ }^{2}$ \\ ${ }^{1}$ Instytut Zoologiczny, Uniwersytet Wrocławski, ${ }^{2}$ Muzeum Przyrodnicze, Uniwersytet Wrocławski}

Gonads of individuals of various ages (young of different number of whorls, adult before and after reproduction) were examined with standard histological methods. No gonad primordia could be found in individuals of 2 whorls or less. The first germ cells appeared at the stage of 3.3 whorls: few and poorly developed gonad vesicles contained fine mitotically dividing cells and cells in meiotic prophase, with the first growing oocytes in the peripheral parts of the vesicles. At 4-whorl stage the oocytes entered vitellogenesis and increased in volume. In subadult individuals the oocyte volume and the volume of the whole gonad increased considerably, besides the advanced vitellogenic oocytes new oocytes appeared, the number of spermatids increased and the first spermatozoa were observed. The gonad of pre-reproductive adults contained numerous late-vitellogenic oocytes, young growing oocytes and many spermatozoa. In post-reproductive individuals there were no mature oocytes, spermatozoa were few, but the presence of young oocytes and mitotically dividing cells indicated resumption of gamete production.

\section{HYDROBIOLOGICAL REGIONALISATION OF UPPER SILESIA, CRACOW-CZESTOCHOWA UPLAND}

\section{A. MICHALIK-KUCHARZ}

Zakład Hydrobiologii, Katedra Ekologii, Wydział Biologii i Ochrony Środowiska, Uniwersytet Śląski, Katowice

The material was collected in 1998-2001 in fish ponds, clay pits, dam reservoirs, oxbows and ditches. Aquatic habitats of the Cracow-Częstochowa Upland are the poorest in Upper Silesia, with only 19 species 
of aquatic snails. Lymnaea palustris, L. truncatula, L. peregra, Planorbis planorbis, Anisus spirorbis and Gyraulus albus were common. The remaining 13 species were rare. Three species occurred commonly in fish ponds: L. stagnalis, L. peregra and G. albus, and ten species in dam reservoirs: L. stagnalis, L. palustris, L. truncatula, L. auricularia, L. peregra, P. planorbis, A. spirorbis, G. albus, G. crista and Planorbarius corneus. No constant aquatic snail community could be distinguished in the region; all the species co-occurred sporadically. Hydrologically the Cracow-Częstochowa Upland is the closest to the Silesian Lowland, but the aquatic snail communities of the two regions are dissimilar.

\section{A RECORD OF ANODONTA WOODIANA (LEA) FROM THE SIERAKOWSKI LANDSCAPE PARK}

\section{T. MIZERA, M. URBAŃSKA}

Katedra Zoologii, Akademia Rolnicza im. A. Cieszkowskiego, Poznań

The first five specimens of Anodonta woodiana, of shell length 17-25 cm in fish ponds in Samita, Wronki district, Wielkopolskie voyvodeship, were caught in July 2002. In September of the same year hundreds of large individuals were observed in the deepest part of the pond. In the shallow part Anodonta anatina was very abundant. Most probably, A. woodiana appeared in the pond five years earlier, as a result of stocking with carp fry from Gosławice near Konin.

\section{EFFECT OF TEMPERATURE ON WINTER TORPOR OF THE ROMAN SNAIL}

\section{A. NOWAKOWSKA, M. CAPUTA,}

J. ROGALSKA, K. WENTOWKA

Zakład Fizjologii Zwierząt, Instytut Biologii Ogólnej i Molekularnej, Uniwersytet Mikołaja Kopernika, Toruń

In order to study the preferred temperatures during natural onset of winter torpor, snails were placed in a chamber with linear thermal gradient and their preferences were registered during three weeks. Another experiment, in the middle of winter, involved snails in natural torpor, placed in various thermal conditions in order to study the latency of activity resumption and preferences immediately after. An experiment carried out in March was aimed at ascertaining if the snails were able to get active in spring in spite of the constant temperature of $5^{\circ} \mathrm{C}$ and darkness. In autumn the snails were not capable of active selection of increasingly lower temperatures. No individual formed an epiphragm and entered winter torpor. Activity resumption in the middle of winter proved to be strictly dependent on the ambient temperature: the snails got active when the temperature exceeded $10^{\circ} \mathrm{C}$, and the latency was in inverse proportion to temperature. A three-week acclimation at $5^{\circ} \mathrm{C}$ in short-day conditions (8L:16D) resulted in a significant increase in glycerol concentration in the haemolymph, while there were no significant changes in the long-day (16L:8D) group at the same temperature. Glycerol concentration in the haemolymph in the group acclimated at $5^{\circ} \mathrm{C}$ during three weeks in summer was nearly three times higher than in autumn, but it did not differ significantly from that in specimens examined in the middle of winter. The concentration in groups acclimated at $5^{\circ} \mathrm{C}$ and 8L:16D during three weeks in summer did not differ compared to the autumn group. Entering the torpor and its duration seem to depend on ambient temperature, but resumption of activity is a controlled process, independent from temperature and light:dark cycle.

\section{REACTION OF AQUATIC MOLLUSCS TO OPENING OF AN OXBOW (OSOKOWY STAW) OF THE SŁUPIA RIVER}

\section{K. OBOLEWSKI}

Zakład Ekologii i Ochrony Morza, Pomorska Akademia Pedagogiczna, Słupsk

The areas adjacent to the Stupia River abound with drainage ditches and canals. The ditches connect fragments of numerous oxbows on both banks of the river. They were dug in 1915-1919 and 1922, when 50 oxbows were cut off. Osokowy Staw contains water throughout the year and is 0.27 ha in surface area. In 2000 it was re-connected with the Słupia River. For comparison, another, unconnected, oxbow Koński staw, and a section of the river at the level of Osokowy Staw, were studied. Molluscs were surveyed in 1999-2002. In the first year of studies there were no snails or bivalves on the bottom of the oxbow. The situation improved with introduction of river water: members of the genus Pisidium dominated in the study period in the oxbow and the river. Snails Lymnaea stagnalis L., Acroloxus lacustris L., Planorbarius corneus L. - were fairly numerous on Stratiotes aloides L. Because of an improvement in physico-chemical parameters of water, the connection with the river resulted in a rapid increase in the biomass compared to the unconnected Koński Staw (mean gastropod biomass twice higher); in 2002 a further increase in snail biomass on Stratiotes was observed.

\section{AN UNUSUAL MODE OF SHELL GROWTH IN UNIONID ONTOGENY}

\section{B. ORZECHOWSKI}

Zakład Ekologii i Ochrony Morza, Pomorska Akademia Pedagogiczna, Słupsk

The aim of the study was an estimate of weight of shell valves depending on their length in age-size 
classes. The material included a few populations of Unio tumidus Philipsson and Anodonta anatina L. In $U$. tumidus initially the left shell valve showed a faster increase in weight in four, and the right valve in one population. In one population the growth of both valves was equal. In $A$. anatina the growth of the right valve was faster in three, and of the left valve in two populations. In older age classes of both species the tendency became reversed, and as a result the valve which initially was slower to grow, reached the larger size.

SHELL POLYMORPHISM IN CEPAEA NEMORALIS FROM THE EASTERN DISTRIBUTION BORDER

\section{OŻGO}

Instytut Biologii i Ochrony Środowiska, Pomorska Akademia Pedagogiczna, Słupsk

The analysis of colour and banding polymorphism included 8,000 shells from 51 sites in five towns of the Subcarpathian region: Tarnów, Rzeszów, Łańcut, Jarosław and Przemyśl. Yellow shells (71\%) prevailed. Pink shells constituted $29 \%$ and brown shells only $0.06 \%$ (found in Łańcut only). Considering the colour and banding together, yellow, single-banded shells constituted a half of all shells. Pink shells with one band were also numerous $(17 \%)$, as well as yellow five-banded shells $(16 \%)$. The percentage of yellow shells increased eastward, and the tendency results probably from increasing continentalisation of climate. In sunny sites the percentage of yellow shells was significantly higher than in shady sites. In over half sunny sites the frequency of yellow shells exceeded $90 \%$. Significant differences between adjacent localities of different insolation indicate a high rate of adaptation to conditions found at the distribution border.

\section{KARYOLOGICAL STUDIES ON LITHOGLYPHUS PYRAMIDATUS MÖLLENDORFF FORM THE GORYŃ RIVER (W UKRAINE)}

\section{PERSZKO}

Katedra Zoologii, Uniwersytet Pedagogiczny w Żytomierzu, Ukraina

There is no literature information on chromosomes in Lithoglyphidae. According to the currently accepted classification there are four taxa of Lithoglyphus in Eastern Europe: L. apertus (Küster), L. pyramidatus Möllendorff and L. naticoides (C. Pfeiffer) with two subspecies: L. n. naticoides and $L$. $n$. berolinensis (Westerlund). L. pyramidatus was collected in the Goryn River (W Ukraine) in the summer of 2002. Chromosome slides were made with standard methods. The chromosome number is $2 \mathrm{n}=18$; all the chromosomes are macrochromosomes (above $1 \mu \mathrm{m}$ ). The first and second pairs are submetacentric, III-V and VII-IX - metacentric, VI - acrocentric.

\section{IS SPECIES PROTECTION OF MOLLUSCS NECESSARY?}

\section{A. PIECHOCKI}

Katedra Zoologii Bezkręgowców i Hydrobiologii, Uniwersytet Łódzki

The list of molluscs under species protection in Poland includes ca. 60 species which is nearly $25 \%$ Polish fauna. The number is very high compared to other European countries: only three species of bivalves are protected in the Czech Republic (Margaritifera margaritifera, Anodonta cygnea and Unio pictorum), and 22 snail and two bivalve species in Slovakia. The inclusion in the list is often ungrounded. Problems implied by legislation are in many cases an obstacle in ecological, hydrobiological and faunistic studies. Any field work which involves collecting protected species requires a permission from the voyvode or even ministry. This is especially important for benthos-studying hydrobiologists since no larger sample of bottom fauna can be taken without sphaeriids all of which (21 species) are under protection in Poland. It seems reasonable that species protection should apply only to easily identifiable, attractive molluscs which are valuable to collectors (e.g. some large unionids, helicids, clausiliids). Small molluscs which are difficult to find require protection in nature reserves and national parks rather than status of protected species.

\section{A CONCEPT OF A GUIDE TO AQUATIC MOLLUSCS OF POLAND, WITH NOTES ON MODERN TAXONOMY OF SNAILS AND BIVALVES}

\section{A. PIECHOCKI ${ }^{1}$, B. WAWRZYNIAK-WYDROWSKA ${ }^{2}$ \\ ${ }^{1}$ Katedra Zoologii Bezkręgowców i Hydrobiologii, Uniwersytet Łódzki, ${ }^{2}$ Zakład Paleooceanologii, Uniwersytet Szczeciński}

The authors are preparing a modern guide to all freshwater and marine (Baltic) molluscs of Poland. The guide will include colour photos of shells. The photos will show essential features, such as shell shape and sculpture, aperture shape, operculum etc. SEM photos will show hinge structure in bivalves. Besides, the book will contain a general part dealing with morphology, anatomy, biology and ecology. Species descriptions will include shell and soft parts, variation, bionomics and distribution. The systematic arrangement will correspond to that proposed for the 
programme Fauna Europaea; there are considerable changes regarding prosobranch snails, as well as some pulmonates, e.g. lymnaeids and planorbids.

\section{DISTRIBUTION AND ROLE OF MACOMA BALTHICA IN THE POLISH ZONE OF THE BALTIC}

\section{Z. PIESIK ${ }^{1}$, J. KEMPTER ${ }^{2}$, E. WNUK-GŁOWEDEL ${ }^{3}$}

${ }^{1}$ Zakład Ekologii i Ochrony Morza, Pomorska Akademia Pedagogiczna, Słupsk, 2Zakład Parazytologii, Akademia Rolnicza, Szczecin, ${ }^{3}$ Drawieński Park Narodowy, Drawno

Populations of Macoma balthica were studied in the Polish shore zone of the Baltic (to 3 miles), in the Gulf of Pomerania and in the open coast of Middle Pomerania. Density, wet biomass and frequency of Macoma were determined for the regions of the mouths of rivers Odra, Wieprza, Słupia, Łupawa and Łeba. The frequency of Macoma in the zone was $77.4 \%$ while in the open sea it was $39.8 \%$. The density in the shore zone ranged from 0 to 304 indiv. $/ \mathrm{m}^{2}$, the wet mass from 0 to $99.2 \mathrm{~g} / \mathrm{m}^{2}$. M. balthica found better conditions in the Gulf of Pomerania compared to Middle Pomerania (density 4.5 times higher, wet mass 2.5 times higher). M. balthica provides food resources for birds and fishes and contributes to water purification (biofiltration, biosedimentation).

\section{POPULATION DYNAMICS OF VERTIGO MOULINSIANA (DUPUY) (GASTROPODA: PULMONATA: VERTIGINIDAE) FROM BAGNOR IN S ENGLAND}

\section{B. M. PokryszKO ${ }^{1}$, I. J. KiLLEEN ${ }^{2}$}

${ }^{1}$ Muzeum Przyrodnicze, Uniwersytet Wrocławski, ${ }^{2}$ Malacological Services, Felixstowe, UK

Translocation of a fragment of habitat with a part of a snail population is one of the recently introduced means of active protection of molluscs. In 1996 a part of a threatened population of Vertigo moulinsiana in Bagnor in S England was translocated to a new and safe site. It was monitored during the next three years, resulting in a good basis for an analysis of its abundance dynamics and age structure. The results indicate three reproductive periods: spring (April), early autumn (September) and winter (December). Growth to maturity probably takes at most 4 months and the life span seems not to exceed half a year. Out of 15 European species of Vertigo, growth rate, number of generations per year and reproductive period are known only for $V$. pusilla, V. angustior and V. geyeri. All the studied species of Vertigo have short life cycles (not exceeding one year), quick growth and maturity (several months) and reproduce basically once in a lifetime.

\section{SHELL VARIATION IN DREISSENA BUGENSIS ANDR. IN THE RESERVOIR OF THE CHERNOBYL NUCLEAR POWER PLANT}

\section{A. R. Protasov}

Instytut Hydrobiologii UAN, Kijów

The cooling reservoir of Ch. NPP is $21.7 \mathrm{~km}^{2}$ in surface area and $149 \mathrm{mln} . \mathrm{m}^{3}$ in volume. Before the 1986 accident there was a significant increase in water temperature (in the discharge channel from 17.2 up to $32.5^{\circ} \mathrm{C}$, in the intake channel - from 8.2 up to $25.6^{\circ} \mathrm{C}$ within a year). In that period Dreissena polymorpha Pallas settled mainly in the coolest part, basically - in the intake channel. In 1990 D. bugensis Andr. was noted there. In December 2000 the NPP closed down. Based on the thermal history of the reservoir five zones could be distinguished: old cold (OC), new cold (NC), new warm (NW), old warm $(\mathrm{OW})$ and old hot $(\mathrm{OH})$. A hundred specimens of $D$. bugensis were collected in each zone in October 2002. The shell length, height and thickness were measured to the nearest $0.1 \mathrm{~mm}$. The form index Kv was calculated according to the formula: $\mathrm{Kv}=((\mathrm{L}+\mathrm{h}+\mathrm{d}) / 3)^{3} / \mathrm{Lhd}$, where: L- length, hheight, $d-$ thickness of the shell. The size structure differed slightly between the zones (in NW zone dominance peak displaced towards smaller sizes). The external volume of the shell of small specimens (6-10 $\mathrm{mm}$ ) decreased from zone $\mathrm{OC}$ to zone $\mathrm{OH}$, while large specimens (16-20 mm) showed no essential differences. The colour pattern and sculpture of the shells varied between the zones. In zone NW there was no phene $\mathrm{E}$ (diagonal division of colour pattern), the frequency of phenes $\mathrm{G}$ (arched components of the pattern) and L (spots) was the lowest, the frequency of phenes J (wavy components of the pattern) and K (radial components) was the highest; the shell growth was not reflected in its sculpture. Similarity estimate with $r$ criterion showed that zones OC and NC were similar in their colour pattern, zone OW was close to them, while zone NW was dissimilar ( $\mathrm{r}$ parameter significantly different from 1). Likewise, zone $\mathrm{OH}$ was different from the remaining zones. In zones $\mathrm{OC}$ and $\mathrm{NC}$ the proportion of asymmetrical specimens was $9 \%$, while in the other zones it ranged from 0 to $3 \%$.

\section{SHELLS OF HELIX AS INDICATORS OF ACCUMULATION IN BIOMONITORING OF SOME TRACE ELEMENTS}

\section{RAĆ, Z. MACHOY}

Katedra i Zakład Biochemii i Chemii, Pomorska Akademia Medyczna, Szczecin

The objective of the study was to determine the degree of accumulation of fluorides and selected metals $(\mathrm{Cu}, \mathrm{Zn}, \mathrm{Pb})$ in shells of Helix from natural habitats 
(vicinity of Szczecin and the Poprad National Park in Slovakia) and laboratory culture (snails fed with standard mixture with addition of sodium fluoride, copper, zinc and lead nitrates). Fluoride content in shells was determiend with ion-selective fluoride electrode, metal content - with atomic absorption spectrometry. Differences in fluoride content in shells of Helix from natural habitats versus laboratory indicate a possibility of using the shells for fluoride pollution biomonitoring, but the shells seem to be useless for metal biomonitoring.

\section{A FEW WORDS ABOUT THE CLECOM PROJECT}

\section{A. RIEDEL}

\section{Muzeum i Instytut Zoloogii PAN, Warszawa}

The classification system adopted by the authors of the CLECOM Project (Check-List of the European Continental Mollusca) raises numerous objections, and introducing it as obligatory does not seem advisable. It does not ensure stability and univocality of mollusc nomenclature. Some of the taxonomic acts from the first edition of the Check-List are in disagreement with the basic assumptions of the International Code for Zoological Nomenclature (e.g. uncritical resurrection of obliterated names is a misuse of the priority principle), other find no support in taxonomic and phylogenetic studies (e.g. elevating names of forms or subspecies to specific rank, resurrecting species names - synonyms proposed by representatives of the French Nouvelle Ecole, splitting or lumping families or genera without presenting any arguments or citing relevant literature).

\section{SIZE STRUCTURE OF YOUNG DREISSENA POLYMORPHA PALL. IN HETEROGENEOUS HABITAT CONDITIONS}

\section{O. O. SINICYNA ${ }^{1}$, B. ZDANOWSKI ${ }^{2}$}

${ }^{1}$ Instytut Hydrobiologii UAN, Kijów,

${ }^{2}$ Instytut Rybactwa Śródlądowego, Olsztyn

Preliminary studies in the heated Konin lakes indicate that in summer young $D$. polymorpha $(0.25-5.5$ $\mathrm{mm}$ ) can occur in various habitats in the lake system, as dominants or subdominants. Their size structure was studied in 2001 and 2002 (July-August), in ten sites. The water temperature ranged from 23.8 to $32.5^{\circ} \mathrm{C}$, the flow from 6 to $25 \mathrm{~m}^{3} / \mathrm{sec}$. The size diversity was estimated with Shannon index. Dominance of particular size classes varied from 17 to $92 \%$. Postlarval stage $(0.25-0.7 \mathrm{~mm})$ dominated in the initial cooling reservoir; in Lake Licheńskie individuals of 2.1-4.0 mm prevailed. Six size groups could be distinguished in the canals; the size range was the widest in the coolest canal $(1.0-3.0 \mathrm{~mm})$ and in the canal connecting Lakes Licheńskie and Pątnowskie $(0.5-2.0 \mathrm{~mm})$. The size structure in this part of the population was diverse (Shannon index 3.146 and 3.436, respectively). An equally significant diversity was characteristic of $D$. polymorpha attached to live Anodonta woodiana in the cooler part of the initial cooling reservoir, Lake Licheńskie and the canal connecting lakes Licheńskie and Pątnowskie.

\section{ENDANGERED SNAILS AND BIVALVES IN UKRAINIAN WATERS}

\section{P. STADNYCHENKO, G. E. KIRICHUK, R. K. Melnichenko, L. N. JanOvich Uniwersytet Pedagogiczny w Żytomierzu, Ukraina}

The decrease in abundance and species richness of aquatic molluscs of Ukraine is associated with changes in physico-chemical properties of the habitats, though the reasons for threat have not been studied in detail. The impoverishment includes dissappearance of some species. During the last 25 years of the 19th c. snails of the genus Fagotia were still present in the Dnester, but they have not been found in the river or its tributaries for 50 years. Lymnaea glabra was reported by earlier authors from NW Ukraine: the San and western Bug basins. It was last found in Ukraine at the beginning of the sixties. Abundance of some species decreases rapidly. Myxas glutinosa, never common in Ukraine, was nonetheless found every year in various parts of the country. Only two specimens were found during the last 15 years. The same pertains to unionids - Unio crassus, sensitive to the presence of ammonia in bottom sediments, seems especially threatened. The vertical range of unionids in lakes and other water bodies is another aspect of the phenomenon; progressive eutrophication results in oxygen deficit in bottom sediments and the presence of toxic $\mathrm{H}_{2} \mathrm{~S}$ and ammonia. As a result the bivalves move to shallow littoral (from the depth of $1-2 \mathrm{~m}$ to $0.2-1 \mathrm{~m})$.

\section{THE EFFECT OF SELECTED EDAPHIC FACTORS ON TERRESTRIAL GASTROPODS IN THE MILITARY SHOOTING AREA BIEDRUSKO NEAR POZNAŃ}

\section{URBAŃSKA}

Katedra Zoologii, Akademia Rolnicza im A. Cieszkowskiego, Poznań

Though the soil acidity affected the number and abundance of species in the studied area, it was not always the most important factor. In some cases the effect of e.g. humidity or insolation was more pro- 
nounced. Low pH did not always imply the low number of gastropods. For those species for which literature data on edaphic requirements existed, it was possible to make comparisons with the obtained results. Columella aspera was found on acid soils ( $\mathrm{pH} 4.9$ and 5.92) of low humus content, low base saturation and low content of exchangeable cations. Carychium tridentatum preferred soil of $\mathrm{pH}$ 6.51-6.06 and high $\mathrm{Ca}$ and $\mathrm{Mg}$ content. Cochlicopa lubrica was the most frequent in samples of high $\mathrm{pH}$ and content of exchangeable cations, but was also present at low $\mathrm{pH}, \mathrm{Ca}$ and Mg content. Punctum pygmaeum was found on various soils, but mostly with a high content of assimilable nutrients. Finding Vertigo pygmaea in sites with the lowest and the highest $\mathrm{pH}$ suggests that acidity is not the limiting factor for this species. Discus rotundatus was found on soils of rather high $\mathrm{pH}$ and rich in assimilable potassium and magnesium.

\section{THE EFFECT OF TREMATODE INVASION ON THE DAILY FOOD CONSUMPTION BY LYMNAEA OVATA}

\section{O. VASYLENKO}

Katedra Zoologii, Uniwersytet Pedagogiczny w Żytomierzu, Ukraina

Uninfected snails consumed all the food proposed. The highest percentage was formed of Populus leaves; the mean daily ratio was $4.68 \pm 0.31 \%$, including 1.9 Alisma leaf, 12.4 Carex blade and 3.1 Salix leaf. Infected snails showed a rapid increase in consumption of all kinds of food, the increase being the most significant for Alisma leaves $(2.4 \times)$ and Carex blades $(1.8 \times)$. The snail reaction to the presence of parasites seems to be non-specific, and consists in a generally increased metabolic rate manifest as increased food consumption.

\section{HEART-BEAT IN LYMNAEA STAGNALIS UNDER THE EFFECT OF HEAVY METALS AND PARASITE INFECTION}

\section{A. VySKUSHENKO}

Uniwersytet Pedagogiczny w Żytomierzu, Ukraina

The aim of the study was to test the possibility of using Lymnaea stagnalis (L.) and its heart-beat as an indicator of water toxicity. The normal heart-beat frequency in L. stagnalis is $17.5 \pm 0.4$ and in infected snails $-17 \pm 0.4$ per minute. A weak parasite infection did not change the frequency. At a medium-intensity infection, as a result of increase in the general metabolic rate (reaction to parasite), the heart-beat was acceler- ated. At an intense infection bradycardia was observed. Exposure of uninfected and infected $L$. stagnalis to a solution containing $1 \mathrm{mg} / \mathrm{dm}^{3}$ of copper sulphate resulted in a decrease in heart-beat by ca. $50 \%$. Nevertheless, when exposed to a $0.2 \mathrm{mg} / \mathrm{dm}^{3}$ solution, both the weakly infected animals and individuals with intense infection reacted by increasing their general metabolism level. Their heart-beat increased by up to $11 \%$ compared to the normal frequency.

\section{HELICELLA OBVIA MENKE FROM THE REGION OF OSOWIEC (NE POLAND)}

\section{W. WOJTAŚ}

Zakład Zoologii, Instytut Biologii, Akademia Pedagogiczna, Kraków

Width of protoconch, size of increment since hatching, shell height and diameter and aperture height were measured in shells from two sites. Site I was an open, sunny, fallow land on the edge of a pine forest, with xerophilous plants (Sedum acre L., Erigeron canadiensis L., Agrostis tenuis Sibth.). Site II was a strip of herbaceous vegetation between a pine forest and a road, with Agrostis tenuis Sibth., Taraxacum officinale Web. ex Wiggers and Melilotus albus L., shaded by the forest during a part of the day. The snails from site II were larger in terms of shell height and diameter and protoconch width, which may suggest a direct habitat effect.

\section{THE EFFECT OF DIGENETIC TREMATODE INFECTION ON CA CONTENT IN SHELLS OF LYMNAEA STAGNALIS (L.)}

\section{E. ŻBIKOWSKA}

Zakład Zoologii Bezkręgowców, Instytut Biologii Ogólnej i Molekularnej, Uniwersytet Mikołaja Kopernika, Toruń

Calcium content in water and snail shells was measured with EDTA method. Half of 1,680 specimens from 6 lakes were trematode-infected, the other half were control specimens (not infected). Only in the lake with the lowest calcium content the Ca content in shells of infected snails was higher compared to uninfected snails. This does not provide evidence for hypercalcification under the effect of trematodes. The Ca content in the haemolymph of infected and uninfected snails from the same lake was similar. The data may suggest that the shell is a storage place for any excess calcium, while its concentration in the haemolymph is maintained at a constant level, necessary for normal functioning of the organism. 